\title{
Research in disaster and social capital: Mapping out the themes and findings
}

\author{
Ratna Mulyany ${ }^{11^{*}}$, Zata Hulwani Zuhri ${ }^{2}$, and Heru Fahlevi ${ }^{3}$ \\ ${ }^{1,2,3}$ Department of Accounting, Universitas Syiah Kuala, Jl. Tgk. Syech Abdul Rauf, Banda Aceh, 23111, Indonesia
}

\begin{abstract}
Research in the field of disaster has been growingly and widely conducted primarily in response to the local and global disaster phenomena which has also witnessed an increasing trend over the time. Meanwhile, social capital has been recognized as a key element in disasters' recovery and resilience. This study employs qualitative standpoint to identify the findings and themes of research linking the issues of disaster and social capital. In selecting and critically appraising all the relevant studies in the topic of disaster and social capital, systematic review method was adopted. Using the Scopus database to identify relevant articles, this study reviewed 39 articles published in (accounting and business) journals indexed in Scopus from 1990 to 2020. The finding identifies several research themes within the interaction of disaster and social capital. Five sub-clusters were identified consisting of research focused on bridging social capital, bonding social capital, the factors, the role, social participation, and obstacles. Findings from each subcluster were mapped out and it generally indicates somehow synchronous patterns of findings from each cluster indicating the various essential roles of social capital were highlighted for the disaster resilience and recovery process.
\end{abstract}

\section{Background}

The occurrences of disasters, such as earthquakes, hurricanes, floods and droughts, and also Tsunami have the power not only to upend the lives of local residents but also bring the direct and indirect impacts through all of the life facets, as well as economy. This catastrophe has been a wide concern and critical issue to field study, not only science, economics, but also through all of the field of studies. Moreover, the number of studies regarding the disaster keep growing, and most of that literature often link to the social capital which commonly play a role in disaster relief [1-3]. Social capital provides economic and social benefits both to the individuals involved and to other parties such as growing solidarity, easy access to information, diffusion of information, and togetherness in completing social tasks [4]. Therefore, social capital according to [5-7]. has been identified as a key factor in disaster recovery and resilience.

Research in the field of disaster has been growingly and widely conducted primarily in response to the local and global disaster phenomena which has also witnessed an increasing trend over the time [8]. On the other hand, social capital has been recognized as a key element in recovery and resilience to disasters [2]. There has also been extensive research on social capital carried out by various authors from various fields of science dominated mainly by the fields of sociology, economics, organization and politics [9]. The pandemic does not stop some parties from helping each other and this action is a form of social capital. The successful social action in delivering help for disaster relief happened for example in the Philippines during the pandemic. In November 2020, Typhoon Ulyssess flooded communities and damaged the local property in Luzon, Philippine. With the threat of Covid-19 pandemic the Filipinos succeeded in raising donation and relief initiatives through social media [10]. This is also done in Indonesia. As Indonesia has experienced more than hundreds of disasters during the pandemic, the social action was apparent among general public and also corporate. Such social action even involves large scale corporations operating in the country [11].

Intertwining these two major constructs of disaster and social capital, a number of research have looked into the different interaction between disaster and social capital and it is therefore seen interesting to map out the progress of literature discussing the interaction between the two. Motivated by this notion, this study aims to identify the themes and findings of research linking the issues of disaster and social capital. It seeks to classify the clusters of research linking disaster and social capital. It then outlines important findings for each of clusters identified. The rest of this paper is structured as follow. Next section briefly describes the research method of this study followed by result. The last section concludes.

\section{Method}

Systematic literature review method was used in selecting and critically appraising all the relevant studies

\footnotetext{
* Corresponding Author: ummuhaziq@unsyiah.ac.id
} 
in the topic of disaster and social capital. This method enables the discovery of the patterns of prior findings, comprehend the depth of the existing knowledge in the filed and identify gaps for future investigations [43]. This kind of research method revolves around identifying and fundamentally assessing the relevant research which the objective is to identify all empirical evidence that fits predetermined inclusion criteria to answer a particular research question or hypothesis [12]. Essentially the foundation of all types of research lies in the literature reviews yet bias has to be minimized in reviewing articles by using the systematic methods, hence the reliable findings will be provided from which conclusions can be drawn and decisions made [13]. This study used the Scopus database to collect articles on the intertwine between disaster and social capital. Using keywords search on title and abstracts ('Disaster' and 'Social Capital) and year filter from 1990 to 2020. A further filtering process was performed by classifying and coding papers into three categories which are 0 for irrelevant articles, The systematic review procedure which was performed resulted in 724 articles being collected. From 724 articles, 561 articles were removed as the article topics are outside our research objective and 39 articles were considered as directly relevant to the research objective.

\section{Result}

An in-depth exploration into the research focus in this field leads to the identification of several research subclusters and themes within the interaction between disaster and social capital. Despite the various dimensions that may be explored from research linking the two notions of disaster and social capital, the focus of this study is specifically to look into clusters of the studies and subsequently map out the findings from the literature. As depicted in Table 1, five sub clusters were identified consisting of bridging social capital, bonding social capital, the factors, the role, social participation, and obstacles. On the first two sub clusters, while bridging social capital is concerned about the connections between individuals who are dissimilar with respect to socioeconomic and other characteristics, while bonding social capital is with regards to the connections within a group or community characterised by high levels of similarity in demographic characteristics, attitudes, and available information and resources. Bridging and bonding social capital have been noted to play role differently within disaster and they have been two of the most focused research areas in the relationship of disaster and social capital.

Interestingly quite synchronous findings can be identified within each sub-cluster. For example, studies exploring the bridging social capital found that bridging and linking social capital has resulted into many advantages to the process of disaster recovery among others it increased the aid amount [16], [19], it also significantly minimize the impact of life stress among the survivors [20], and also creates longer term survival and wider neighborhood and community revitalization [21]. Likewise with bonding social capital, studies in this sub-cluster found the range benefits of the establishment of bonding social capital in which it protected the survivors of a disaster against functional capacity decline [41], played a crucial role throughout recovery phases and as immediate support [21], [22], provided the reliance for disaster-prone and susceptible to natural hazards communities [23]. Other studies for instance examined important elements related to bonding social capital such as risk perceptions and selfefficacy [24] as well as culture which is deemed relevant in the bonding social capital discussion [23].

Other stream of research connecting the disaster and the concept of social capital were concerned about the various factors which may contribute to the successful relationship between disaster resilience and social capital. For example studies indicating the importance of place and geographical location for building up social capital and community disaster resilience[26],[27]. Other studies within this sub-cluster found livelihood recovery factors; formal network in the community, leadership and trusteeship of community-based organizations, capital endowments, social cooperation networks, transportation convenience, and skills acquired from education and rural-urban migration [28], [29].

Another major theme identified from the review is research investigating the various role of social capital in the recovery of disaster. It was found that social capital played an instrumental role in personal, household, and community affected by disaster to recover more easily and quickly [19], [35-37], strengthened the collaborations and partnerships among disaster organizations, mobilizes the public as disaster volunteers, strengthens community resilience and deepens family ties [38], built self-reliance, enhances coping and quickens recovery from disaster [38], and reduced barriers to collective action speeding up recovery and connecting to aid organizations also protecting mental health among survivors with severe disaster damage [39], [40].

The focus on the dimension of social capital such as social participation was also one of the area of research in that social participation was found to protected the survivors of a disaster against functional capacity decline [41] and to relocate functional ability [41]. Additionally there has been also emphasis on the challenges in the role played by social capital in the context of disaster for instance the difficulties in internal and external communication (language barriers and generational divides), and divided memberships of religious institutions can limit/erode the linking and bridging social capital [42]. 
Table 1. Themes and Finding.

\begin{tabular}{|c|c|c|}
\hline Cluster Finding & Sub-Clusters & Main Findings \\
\hline \multirow[t]{6}{*}{ Social Capital } & $\begin{array}{l}\text { Bridging Social } \\
\text { Capital }\end{array}$ & $\begin{array}{l}\text { - Individuals, communities, government and non-government institutions are } \\
\text { worked to build awareness, strengthen, and expand social networks [14-18] } \\
\text { - Having a large network resulted in significantly increased the amount of aid } \\
\text { received [16], [19]. } \\
\text { - Bridging social capital is more important in prevention and intervention efforts } \\
\text { [20]. } \\
\text { - With bridging, social capital had a significant buffering effect against reducing } \\
\text { the impact of life stress within the survivors [20]. } \\
\text { - Bridging and linking social capital offered pathways to longer term survival and } \\
\text { wider neighbourhood and community revitalization [21]. }\end{array}$ \\
\hline & $\begin{array}{l}\text { Bonding Social } \\
\text { Capital }\end{array}$ & $\begin{array}{l}\text { - Bonding social capital played a crucial role throughout recovery phases and as } \\
\text { immediate support [21], [22] } \\
\text { - A disaster-prone and susceptible to natural hazards communities relied on their } \\
\text { social capital (bonding social capital) [23]. } \\
\text { - Both risk perceptions and self-efficacy as bonding social capital have positive } \\
\text { links to social capital [24]. } \\
\text { - The effect of the amount of social capital available through bonding networks } \\
\text { embedded in pre-disaster networks and the resources affected [25]. } \\
\text { - Culture is relevant in the bonding social capital discussion [23]. }\end{array}$ \\
\hline & The Factors & $\begin{array}{l}\text { - The importance of place and geographical location are the ground upon which } \\
\text { social capital and community disaster resilience are built [26],[27]. } \\
\text { - Livelihood recovery factors; formal network in the community, leadership and } \\
\text { trusteeship of community-based organizations, capital endowments, social } \\
\text { cooperation networks, transportation convenience, and skills acquired from } \\
\text { education and rural-urban migration [28], [29]. } \\
\text { - Self-reliance within community factors; shared identity as a close-knit, family- } \\
\text { oriented community of hard workers [30]. } \\
\text { - The three networks (bonding, bridging, and linking) demonstrate different } \\
\text { structural signatures composed of differing forms of social capital that arise } \\
\text { following a natural disaster [31]. } \\
\text { - Disaster significantly increased social capital investment rate [32]. } \\
\text { - Local planning is needed to have greater recognition and anticipation of the } \\
\text { potential social capital [33]. } \\
\text { - Mutual trust and mutual help generate good bonding relationship community } \\
\text { [34]. }\end{array}$ \\
\hline & The Role & $\begin{array}{l}\text { - Social capital played an instrumental role in personal, household, and } \\
\text { community affected by disaster to recover more easily and quickly [19], [35-37]. } \\
\text { - Social capital builds collaborations and partnerships among disaster } \\
\text { organizations, mobilizes the public as disaster volunteers, strengthens } \\
\text { community resilience and deepens family ties [38]. } \\
\text { - Social capital builds self-reliance, enhances coping and quickens recovery from } \\
\text { disaster [38]. } \\
\text { - High levels of social capital reduced barriers to collective action speeding up } \\
\text { recovery and connecting to aid organizations also protecting mental health } \\
\text { among survivors with severe disaster damage [39], [40]. }\end{array}$ \\
\hline & $\begin{array}{l}\text { Social } \\
\text { Participation }\end{array}$ & $\begin{array}{l}\text { - Social participation protected the survivors of a natural disaster against } \\
\text { functional capacity decline [41]. } \\
\text { - Social participation could relocate functional ability [41]. }\end{array}$ \\
\hline & Obstacles & $\begin{array}{l}\text { - The difficulties in internal and external communication (language barriers and } \\
\text { generational divides), and divided memberships of religious institutions can } \\
\text { limit/erode the linking and bridging social capital [42]. }\end{array}$ \\
\hline
\end{tabular}




\section{Conclusion}

Research investigating the intertwined interaction between disaster and social capital has flourished especially taking the settings from the geographical areas which are prone to disaster. There have been several themes identified within the topic of social capital and disaster indicating the diverse emphasis being placed in the effort to connect the two dimensions of disaster and social capital. Despite the various dimensions that may be explored from research linking the two notions of disaster and social capital, the focus of this study is specifically to look into clusters of the studies and subsequently map out the findings from the literature. The finding identifies several research themes within the interaction of disaster and social capital. Five sub-clusters were identified consisting of research focused on bridging social capital, bonding social capital, the factors, the role, social participation, and obstacles. Findings from each sub-cluster were mapped out and it generally indicates somehow synchronous patterns of findings from each cluster indicating the various essential role of social capital were highlighted for the disaster resilience and recovery process.

Acknowledgments. This paper is part of a research project funded under the Hibah Penelitian Lektor Universitas Syiah Kuala 2021. The authors are grateful to the grant given by the Institute for Research and Community Service or Lembaga Penelitian dan Pengabdian kepada Masyarakat (LPPM) of Universitas Syiah Kuala, Aceh, Indonesia.

\section{References}

1. R. Rustinsyah, R. A. Prasetyo, M. Adib, Int. J. Dis. Risk. Red. 52. (2021)

2. S. Panday, S. Cushton, J. Karki, Balen, A. Barnes, Int. J. Dis. Risk. Red. 55 (2021)

3. D. Hidayati, MATEC Web Conf. 229. (2018)

4. P. S. Adler, S. Kwon, Social capital: The good, the bad, and the ugly. In E. Lesser (Ed.), Knowledge and social capital: Foundations and applications. Boston, MA: Butterworth- Heineman. 89-115. (2000)

5. F. Albrecht, Dis. 42. (2018)

6. D. P. Aldrich, M. Meyer, Amer. Behv. Sci. 59. (2015)

7. R.L. Hawkins, K. Maurer, Bri. J. Soc. Work. 40. (2010)

8. H. Fahlevi, M. Indriani, R. Mulyany, Nadirsyah. What is the Role of Accounting in Disaster Recovery and Relief? A Literature Review, in IOP Conference Series: Earth and Environmental Science. 10-12 October 2018, Banda Aceh, Indonesia, 273 (2019).

9. J. Wallis, P. Killerby, B. Dollery, Int. J. Soc. Eco. 31 (2004)

10. RAPPLER.COM. Filipino bayanihan spirit brings relief, attention to Typhoon Ulysses victims. Retrieved on 19 August 2021 from RAPPLER. COM: https://www.rappler.com/moveph/filipinosbayanihan-brings-disaster-relief-attention -typhoonulysses-victims. (2020, November 17).
11. T. J. Post,. Natural disaster survivors celebrate togetherness during Ramadan. Retrieved from The Jakarta Post: https://www.thejakartapost.com/adv/ 2021/04/15/natural-disaster-survivors-celebratetogetherness-during-ramadan-thanks-to-abc.html. (2021, April 15)

12. H. Snyder. J. Bus. Res. 104 (2019)

13. D. Maher, A. Liberati, J. Tetzlaff, D.G. Altman. An. Int. Med. 151 (2009)

14. J. Mimaki, Y. Taleuchi, R. Shaw. J. Coas. Conserv. 13, 207-2015 (2009)

15. N. Pitas, C. Ehmer, Amer. J. Heal. Prom. 34, 942 (2020)

16. C. Zhang, Y. Fang. Eco. Indic. 116 (2020)

17. W. T. Story, H. Tura, J. Rubin, B. Engidawork, A. Ahmed, F. Jundi, T. Iddosa, T. H. Abrha. Soc. Sci. Med. 257 (2020)

18. A. Tammar, S. S. Abosuliman, K. R. Rahaman. Sust. 12 (2020)

19. J. Wei, Y. Han. Sust. 10, 1 (2018)

20. H. Rafiey, F. Alipour, R. LeBeau, Y. Salimi, S. Ahmadi. Psy. Trauma: Theo. Res. Prac. Pol. (2019)

21. R. B. Bhandari. Dis. Prev. Manag. 23, 314 (2014)

22. K. Nguten-Trung, H. Forbes-Mewett, D. Arunachalam. Int. J. Dis. Risk. Red. 46 (2020)

23. S. C. Bernados Jr, L. A. Ocampo, E. A. Pilapil, N. F. Zamora. Int. J. Soc. Eco. Sust. Dev. 11, 26 (2020)

24. P. Hudson, L. Hadedoorn, P. Bubeck. Int. J. Dis. Risk. Sci. 11, 251 (2020)

25. A. Mukherji. J. Civ. Soc. 10, 119 (2014)

26. R. S. Cox, L. E. Perry. Ame. J. Com. Psy. 48, 395 (2011)

27. S. Naithani, A. K. Saha. Dis. Pre. Manag. Int. J. 30, 179 (2020)

28. Y. Minamoto. Dis. Pre. Manag. 19. 548- (2010)

29. W. Liu, J. Li, L. Ren, J. Xu, C. Li, S. Li. Soc. Indi. Res. 150, 977 (2020)

30. E. Chamlee-Wright, V. H. Storr. T. Socio. Rev. 59, 266 (2011)

31. L. Cheung, J. R. McColl-Kennedy, L. Coote. J. Ser. Mar. 41, 438 (2017)

32. E. Yamamura. Reg. Sci. 95, S143 (2016)

33. M. B. LaLone. J. Appl. Soc. Sci. 6, 209 (2012)

34. S. Sadeka, M. S. Mohamad, M. S. K. Sarkar, A. Q. Al-Amin. Soc. Ind. Res. 150(2), 479 (2020)

35. M. Masud-All-Kamal. S. M. M. Hassan. Nat. Haz. 93, 1547 (2018)

36. M. S. Akbar, D. P. Aldrich. Disasters. 42, 475 (2017)

37. D. P. Aldrich. Nat. Haz. 56, 595. (2010)

38. N. W. Chan, R. Roy, C. H. Lai, M. L. Tan. Int. J. Wa. Res. Dev. 35 (2018)

39. N. Tsuchiya, N. Nakaya, T. Nakamura, A. Narita, M. Kogure, J. Aida, C. Tsuji, A. Hozawa, H. Tomita. Psy. Cli. Neu. 71, 52 (2017)

40. D. P. Aldrich. J. Civ. Soc. 7, 81 (2011)

41. K. Gero, H. Hikichi, J. Aida, K. Kondo, I. Kawachi, Ame. J. Epid. 189, 1369 (2020)

42. C. Ngin, J. H. Grayman, A. Neef, and N. Sanunsilp. Nat. Haz. 103, 299 (2020) 